\title{
CLAY MINERALOGY OF SPODOSOLS WITH HIGH CLAY CONTENTS IN THE SUBALPINE FORESTS OF TAIWAN
}

\author{
Ching-Wei Lin ${ }^{1}$, Zeng-Yei Hseu ${ }^{2}$ and Zueng-S Ang Chen ${ }^{1, *}$ \\ ${ }^{1}$ Department of Agricultural Chemistry, National Taiwan University, Taipei 106-17, Taiwan ROC \\ 2 Department of Environmental Science and Engineering, National Pingtung University of Science and Technology, Nei-Pu, \\ Pingtung 912-01, Taiwan ROC
}

\begin{abstract}
Three Ultic Haplorthods with significant illuviation of clay and spodic materials in the subalpine forests located in the Alishan area of central Taiwan were selected to identify the clay mineral compositions by X-ray diffraction (XRD) and to explain the transformation of the clay minerals. The three pedons are dominated by vermiculite and vermiculite-illite interstratified minerals, and they have minor kaolinite, quartz and gibbsite. No hydroxy interlayered vermiculite (HIV) was found in the E horizon of the three pedons because the forest soils are very acidic and have very low Al contents. The presence of HIV in the spodic (Bhs) and argillic horizons $(\mathrm{Bt})$ of the three pedons was associated with greater free $\mathrm{Fe}$ and $\mathrm{Al}$ contents $\left(\mathrm{Fe}_{\mathrm{d}}\right.$ and $\left.\mathrm{Al}_{\mathrm{d}}\right)$, more favorable $\mathrm{pH}$ ranges, and coatings of organo-metallic complexes which prevented continuous weathering. The specific pedogenic process, clay illuviation and podzolization occurred sequentially in the Alishan area, and induced the unusual clay mineral distribution and transformation. The largest amounts of illite are in the $\mathrm{C}$ horizon and the amounts of vermiculite increased with decreasing soil depths. A reverse distribution between illite and vermiculite through the soil profile was observed. Illite was transformed to vermiculite due to the strong weathering environment associated with extremely low exchangeable K contents. The weathering sequence of clay minerals of Spodosols with fine textures in the study area is proposed as: illite $\rightarrow$ vermiculite (or interstratified vermiculite-illite minerals) $\rightarrow$ HIV and vermiculite.
\end{abstract}

Key Words-Hydroxy Interlayered Vermiculite (HIV), Podzolization, Spodosols, Weathering Sequence, X-ray Diffraction (XRD).

\section{INTRODUCTION}

Spodosols are often found in sandy soils and are widespread in subpolar and alpine climatic regimes but extend into interiors of the mid-latitude continents in some humid areas (Li et al., 1998a; Lundstrom et al., 2000; Padley et al., 1985). Taiwan is a tropical and subtropical region, but Spodosols and Spodosol-like soils are found in the subalpine and alpine forests. These soils are usually in udic or perudic soil moisture regimes and mesic soil temperature regimes with heavy rainfall $(>3,000 \mathrm{~mm} / \mathrm{y})$, but typical Spodosols are generally formed at the flatter summit and backslope positions of microrelief (Chen et al., 1989; Chen et al., 1995; Li et al., 1998a). Some reports indicated that the clay contents of the Spodosols formed in the Central Ridge of Taiwan were generally $>30 \%$ and both podzolization and clay illuviation actually occurred in these soils of Taiwan (Chen et al., 1989; Chen et al., 1995; Hseu et al., 1999; Li et al., 1998a).

Weathering of phyllosilicate minerals involves the progressive removal of $\mathrm{K}$ from mica and $\mathrm{Mg}$ or $\mathrm{Al}$ of the $\mathrm{OH}$ sheet from chlorite, oxidation of $\mathrm{Fe}$ in the octahedral sheet and possible removal of some octahedral cations, so that Spodosols do not have a unique and typical clay mineralogy (McKeague et al., 1983). Quartz and feldspars are commonly found in the A and B horizons

* E-mail address of corresponding author:

soilchen@ccms.ntu.edu .tw of temperate Spodosols developed during the Quaternary, and quartz is found in the clay fraction of all horizons of some tropical Spodosols (Andriesse, 1969). McKeague et al. (1983) suggested that the marked difference in the extent of clay mineral weathering in the $\mathrm{E}$ and Bhs horizons is due in part to the fact that mineral surfaces in the Bhs horizons are presumably coated by organo-metallic complexes and thus prevented from weathering. Harris and Hollien (1999), using XRD, found only quartz in the clay fractions of the E horizons, but the clay of the $\mathrm{Bh}$ horizons was dominated by hydroxy-interlayered vermiculite (HIV) and kaolinite in six pedons of Alaquods in Florida. Quartz dominated the clay fractions of upper, sandy horizons, but kaolinite, smectite and gibbsite were usually more abundant in deeper and finer-textured horizons for Alfic and Ultic Haplaquods in Florida (Harris and Carlisle, 1987; Harris et al., 1987a). Li et al. (1998b) indicated that illite and HIV were the major clay minerals in the spodic (Bhs) horizons of four loamy-skeletal Spodosols, and they concluded that the weathering sequence of the clay minerals is illite and chlorite $\rightarrow$ vermiculite $\rightarrow$ smectite $\rightarrow$ HIV. Harris et al. (1987b) found that soils with thick sandy epipedons showed a variation from the general tendency for HIV to be concentrated in surface horizons, and HIV tended to remain abundant at depth in the E horizons of Haplaquods, but decreased steadily below the E-B boundary. Rich (1968) reviewed hydroxy interlayers in expansible layer silicates such as HIV in 
many soils and sediments to determine the nature of interlayers and the processes by which they form. Rich (1968) also indicated the marked effects of interlayers on the cation exchange capacity, fixation of cations, and on swelling and shrinking of clays.

Various degrees of leaching of spodic materials were found in the fine-textured Ultisols and Spodosols at the Alishan area which is an important subalpine forest of central Taiwan (Li et al., 1998a). The characteristics of Spodosols in Taiwan differ significantly from those of North American and European countries in terms of soil texture (Taiwan's Spodosols have $>30 \%$ clay content (Chen et al., 2002)). According to the related investigations, the clay contents in the studied Spodosol or podzolic soils are generally $>30 \%$, and both podzolization and clay illuviation occurred in these soils in Taiwan (Chen et al., 1995; Li et al., 1998a; Hseu et al., 1999; Chen et al., 2002). Therefore, the clay mineralogy of the Spodosols with fine textures in the B horizon at the Alishan Mountain area of Taiwan are of interest. The objectives of this study were: (1) to identify the composition of clay minerals in the podzolized finetextured soils; (2) to explain the depth distribution of clay minerals in these soils; and (3) to indicate the weathering sequence of clay minerals associated with the pedogenic environment.

\section{MATERIALS AND METHODS}

\section{Site description}

The Alishan Mountain, an important subalpine forest of central Taiwan, is located in Chayi County. These subalpine forest soils, at elevations of 1500 to $3000 \mathrm{~m}$, are derived from marine argillaceous sediments and interbedded sandstone and shale of the late Miocene to early Pliocene. The vegetations is dominated by red cypress (Chamaecyparis formosensis and Tsuga chinen- sis), with minor amounts of pine (Pinus armandii and Trochodendron aralioides). The ground vegetation is dominated by Illicium tashiroi, Schefflera taiwaniana, Rhododendron morii, Yushania niitakayanensis, Polygonum Chinese, and Miscanthus floridulus. Based on the climate data of the Alishan Meteorological Station in last three decades, the annual rainfall is $\sim 4000 \mathrm{~mm}$ and most of it falls from May to September. The average annual air temperature is $10.6^{\circ} \mathrm{C}$. The soil moisture regime is udic or perudic and the soil temperature regime is mesic (Soil Survey Staff, 1999). Three soil pedons were selected from the surveys conducted in the coniferous forest with slopes between $<5$ and 20\% (Figure 1). Chen et al. (2002) described the field morphology and micromorphology for these three pedons and classified them as Ultic Haplorthods (Soil Survey Staff, 1999). These Spodosols have significant clay illuviation in the spodic horizon, very unusual in the formation of Spodosols.

\section{Physical and chemical analysis}

Soil samples were collected from each horizon of the profiles for physical and chemical analysis. Particle-size distribution was determined by the pipette method (Gee and Bauder, 1986). The $\mathrm{pH}$ of air-dried samples $(<2 \mathrm{~mm})$ was determined on a mixture of $1: 1$ soil/ deionized water by glass electrode (McLean, 1982). The organic carbon (OC) content was measured by the Walkley-Black wet oxidation method (Nelson and Sommers, 1982). Cation exchange capacity and exchangeable bases were measured with the ammonium acetate method ( $\mathrm{pH}$ 7.0) (Rhoades, 1982). Free $\mathrm{Fe}\left(\mathrm{Fe}_{\mathrm{d}}\right)$ and $\mathrm{Al}\left(\mathrm{Al}_{\mathrm{d}}\right)$ were extracted by the dithionite-citratebicarbonate (DCB) method (Mehra and Jackson, 1960). Amorphous $\mathrm{Fe}\left(\mathrm{Fe}_{\mathrm{o}}\right)$ and $\mathrm{Al}\left(\mathrm{Al}_{\mathrm{o}}\right)$ were extracted by $0.2 \mathrm{M}$ ammonium oxalate (pH 3.0) (McKeague and Day, 1966). Organic-bound $\mathrm{Fe}\left(\mathrm{Fe}_{\mathrm{p}}\right)$ and $\mathrm{Al}\left(\mathrm{Al}_{\mathrm{p}}\right)$ were

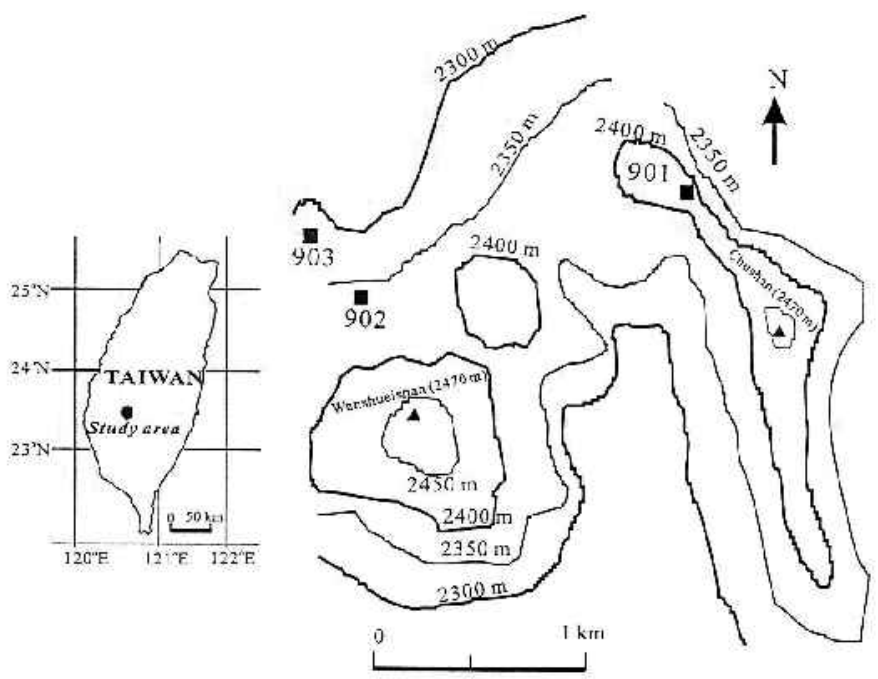

Figure 1. Locations of three pedons in the Alishan Mountain area in central Taiwan. 
extracted by $0.1 \mathrm{M}$ sodium pyrophosphate $(\mathrm{pH} 10.0)$ (Loveland and Digby, 1984). All the metals were determined by atomic absorption spectrometry (Hitachi, 180-30 type).

\section{$X$-ray diffraction of the clay minerals}

Air-dried samples were pretreated with $30 \% \mathrm{H}_{2} \mathrm{O}_{2}$ to remove organic matter, then treated with $\mathrm{DCB}$ to remove the oxide coating materials. The clay fraction was separated by the pipette method (Gee and Bauder, 1986). X-ray diffraction (XRD) analysis was performed on the oriented $\mathrm{K}$ - and $\mathrm{Mg}$-saturated clay samples. The clays were treated with $6 \mathrm{~N} \mathrm{HCl}$ to destroy chlorite and to facilitate identification of vermiculite (Chen, 1977). The expansion properties of the $\mathrm{Mg}$-saturated samples were determined using ethylene glycol solvation at $65^{\circ} \mathrm{C}$ for $24 \mathrm{~h}$. The K-saturated samples were subjected to successive heat treatments at 110,350 and $550^{\circ} \mathrm{C}$ for $2 \mathrm{~h}$. The oriented clays were examined using a Rigaku Miniflex X-ray diffractometer with Ni-filtered $\mathrm{CuK} \alpha$ radiation generated at $30 \mathrm{kV}$ and $10 \mathrm{~mA}$. The XRD patterns were recorded from 3 to $40^{\circ} 2 \theta$ with a scanning speed of $0.5^{\circ} 2 \theta \mathrm{min}^{-1}$. The identification and semi- quantitative determination of the clay minerals were based on the difference of reflection patterns from the $\mathrm{K}$-saturated, Mg-saturated, glycolated, heated and airdried samples (Brindley, 1980; Brown and Brindley, 1980).

\section{RESULTS AND DISCUSSION}

\section{Chemical properties of the three soil pedons}

The clay has accumulated to a significant extent in the lower portions of the pedons, including the Bt and Bhs horizons of the three pedons (Table 1). Various clay coatings in the Bt and Bhs horizons were also identified by micromorphology, reported by Chen et al. (2002) for these three pedons. The $\mathrm{pH}$ values of three soils ranged 3.5-4.9. The $\mathrm{pH}$ values of all $\mathrm{Bhs}$ and $\mathrm{Bt}$ horizons are lower than the $\mathrm{pH}$ value $(\mathrm{pH} \leqslant 5.9)$ defined in spodic materials (Soil Survey Staff, 1999). The organic carbon (OC) content of the spodic horizon (Bhs) was significantly higher than that of the albic horizon (E) of the three soils. The strong leaching processes in the $\mathrm{E}$ horizons resulted in lower $\mathrm{pH}$ values $(<4.5)$ and $\mathrm{OC}$ contents $(<20 \mathrm{~g} / \mathrm{kg})$. These strong leaching processes are

Table 1. The selected physical and chemical properties of the three soil pedons.

\begin{tabular}{ccccc}
\hline Horizon & $\begin{array}{c}\text { Texture } \\
\text { Depth } \\
\mathrm{cm}\end{array}$ & Sand $\begin{array}{l}\text { Silt Clay } \\
\mathrm{g} / \mathrm{kg} \_-\end{array}$ & $\mathrm{pH}$ & $\mathrm{OC}^{1}$ \\
$\mathrm{~g} / \mathrm{kg}$
\end{tabular}

Pedon 901 (Ultic Haplorthods)

$\begin{array}{lrccc}\mathrm{O} & 28-0 & - & - & - \\ \mathrm{O} / \mathrm{A} & 0-5 & 519 & 278 & 203 \\ \mathrm{E} & 5-11 & 568 & 204 & 228 \\ \mathrm{Bhs} & 11-17 & 491 & 184 & 325 \\ \mathrm{Bt} 1 & 17-42 & 395 & 188 & 417 \\ \mathrm{Bt} 2 & 42-67 & 390 & 166 & 443 \\ \mathrm{BC} & 67-92 & 430 & 153 & 416 \\ \mathrm{C} & >92 & 598 & 230 & 172\end{array}$

$\begin{array}{rr}3.5 & 374 \\ 3.5 & 149 \\ 3.7 & 18 \\ 4.2 & 32 \\ 4.8 & 23 \\ 4.9 & 23 \\ 4.9 & 17 \\ 4.9 & 12\end{array}$

\begin{tabular}{cccccc}
\multicolumn{5}{c}{ Exchangeable bases } & Sum of \\
$\mathrm{K} \quad \mathrm{Na} \quad \mathrm{Ca}$ & $\mathrm{Mg}$ & $\begin{array}{c}\text { cations } \\
\text { cations }\end{array}$ & $\mathrm{CEC}^{2}$ & $\mathrm{BS}^{3}$ \\
\hline
\end{tabular}

Pedon 902 (Ultic Haplorthods)

$\begin{array}{lrccc}\mathrm{Oi} & 4-0 & - & - & - \\ \mathrm{Oe} / \mathrm{A} & 0-8 & 428 & 310 & 262 \\ \mathrm{Oa} / \mathrm{A} & 8-14 & 456 & 245 & 300 \\ \mathrm{E} & 14-18 & 560 & 246 & 19 \\ \mathrm{Bhs} & 18-30 & 490 & 266 & 244 \\ \mathrm{Bt} & 30-46 & 478 & 199 & 324 \\ \mathrm{2E} & 46-53 & 515 & 307 & 178 \\ \text { 2Bw } & 53-66 & 500 & 253 & 247\end{array}$

$\begin{array}{rr}3.8 & 277 \\ 4.0 & 145 \\ 3.5 & 89 \\ 4.0 & 15 \\ 4.4 & 22 \\ 4.6 & 18 \\ 4.7 & 3 \\ 4.7 & 13\end{array}$

$\begin{array}{llll}0.57 & 0.12 & 0.10 & 0.08 \\ 0.56 & 0.13 & 0.02 & 0.06 \\ 0.46 & 0.11 & 0.01 & 0.04 \\ 0.47 & 0.12 & 0.06 & 0.01 \\ 0.40 & 0.11 & 0.01 & 0.04 \\ 0.32 & 0.12 & \text { n.d. } & 0.01 \\ 0.34 & 0.13 & \text { n.d. } & 0.01 \\ 0.32 & 0.13 & 0.01 & 0.01\end{array}$

$\begin{array}{rrr}0.9 & 76.4 & 1 \\ 0.8 & 35.7 & 2 \\ 0.6 & 21.5 & 3 \\ 0.7 & 30.5 & 2 \\ 0.6 & 22.1 & 2 \\ 0.4 & 13.1 & 3 \\ 0.5 & 9.0 & 5 \\ 0.5 & 7.0 & 6\end{array}$

Pedon 903 (Ultic Haplorthods)

\begin{tabular}{lrrrrrrrrrrrrr} 
Oe & $10-0$ & - & - & - & 4.4 & 82 & 1.02 & 0.34 & 0.47 & 0.19 & 2.0 & 19.7 & 10 \\
A & $0-4$ & 604 & 254 & 142 & 3.9 & 31 & 0.99 & 0.32 & 0.13 & 0.04 & 1.5 & 14.3 & 10 \\
E & $4-13$ & 635 & 240 & 126 & 4.4 & 8 & 0.88 & 0.30 & 0.07 & 0.02 & 1.3 & 14.1 & 9 \\
EB & $13-30$ & 574 & 254 & 171 & 4.5 & 10 & 0.91 & 0.28 & 0.04 & 0.01 & 1.2 & 17.0 & 7 \\
Bhs/Bt & $30-44$ & 490 & 232 & 288 & 4.5 & 26 & 1.01 & 0.31 & 0.06 & 0.02 & 1.4 & 21.6 & 7 \\
BC & $44-70$ & 454 & 266 & 280 & 4.5 & 22 & 0.99 & 0.32 & 0.10 & 0.02 & 1.4 & 19.1 & 7 \\
\hline
\end{tabular}

${ }^{1}$ Organic carbon

2 Cation exchangeable capacity

${ }^{3}$ Base saturation percentage

n.d.: Not detectable

-: Not determined

$\begin{array}{rrlllll}0.71 & 0.14 & 0.12 & 0.14 & 1.1 & 51.0 & 2 \\ 0.68 & 0.15 & 0.04 & 0.08 & 0.9 & 38.7 & 2 \\ 0.77 & 0.13 & 0.01 & 0.07 & 1.0 & 36.5 & 3 \\ 0.54 & 0.14 & \text { n.d. } & 0.02 & 0.7 & 11.8 & 6 \\ 0.50 & 0.13 & 0.01 & 0.02 & 0.7 & 15.8 & 4 \\ 0.47 & 0.13 & \text { n.d. } & 0.02 & 0.6 & 12.0 & 5 \\ 0.44 & 0.16 & \text { n.d. } & 0.01 & 0.6 & 13.7 & 4 \\ 0.50 & 0.15 & \text { n.d. } & 0.01 & 0.7 & 13.6 & 5 \\ & & & & & & \\ & & & & & & \\ 1.02 & 0.34 & 0.47 & 0.19 & 2.0 & 19.7 & 10 \\ 0.99 & 0.32 & 0.13 & 0.04 & 1.5 & 14.3 & 10 \\ 0.88 & 0.30 & 0.07 & 0.02 & 1.3 & 14.1 & 9 \\ 0.91 & 0.28 & 0.04 & 0.01 & 1.2 & 17.0 & 7 \\ 1.01 & 0.31 & 0.06 & 0.02 & 1.4 & 21.6 & 7 \\ 0.99 & 0.32 & 0.10 & 0.02 & 1.4 & 19.1 & 7\end{array}$


Table 2. The selected $\mathrm{Fe}$ and $\mathrm{Al}$ properties of the three soil pedons.

\begin{tabular}{ccccccccc}
\hline Horizon & $\begin{array}{c}\text { Depth } \\
\mathrm{cm}\end{array}$ & $\mathrm{Fe}_{\mathrm{d}}{ }^{1}$ & $\mathrm{Al}_{\mathrm{d}}$ & $\mathrm{Fe}_{\mathrm{o}}{ }^{1}$ & $\mathrm{Al}_{\mathrm{o}}$ & $\mathrm{Fe}_{\mathrm{p}}{ }^{1}$ & $\mathrm{Al}_{\mathrm{p}}$ & $\begin{array}{c}\mathrm{Al}_{\mathrm{o}}+(1 / 2) \mathrm{Fe}_{\mathrm{o}} \\
\%\end{array}$ \\
\hline
\end{tabular}

Pedon 901 (Ultic Haplorthods)
O $\quad 28-0$

O $28-0$

$\mathrm{O} / \mathrm{A}$

$0-5$

$\mathrm{E}$

$5-11$

$\begin{array}{ll}\text { Bhs } & 11-17 \\ \text { Bt1 } & 17-42\end{array}$

Bt2 42-67

BC $\quad 67-92$

C $>92$

25.6

$\begin{array}{cccc}- & - & - & - \\ 1.7 & 3.0 & 3.6 & 3.7 \\ 2.1 & 7.7 & 3.6 & 9.0\end{array}$

11.1

$-\overline{0} 51$

42.8

60.2

$\begin{array}{rrrr}19.6 & 22.0 & 9.4 & 33.5\end{array}$

11.5

0.74

$\begin{array}{lllll}62.5 & 24.7 & 14.7 & 16.9 & 26.1\end{array}$

20.3

$\begin{array}{lllllll}66.1 & 15.8 & 11.2 & 12.2 & 18.6 & 22.6 & 1.78\end{array}$

$\begin{array}{lllllll}51.9 & 12.9 & 8.7 & 9.4 & 13.5 & 20.4 & 1.37\end{array}$

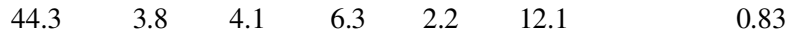

Pedon 902 (Ultic Haplorthods)

$\begin{array}{lrrrrrrrr}\mathrm{Oi} & 4-0 & - & - & - & - & - & - & - \\ \mathrm{Oe} / \mathrm{A} & 0-8 & 32.6 & 2.2 & 6.2 & 9.0 & 7.1 & 11.1 & 1.21 \\ \mathrm{Oa} / \mathrm{A} & 8-14 & 23.1 & 1.7 & 5.9 & 9.4 & 4.8 & 11.7 & 1.22 \\ \mathrm{E} & 14-18 & 37.6 & 1.3 & 8.4 & 8.6 & 5.5 & 11.0 & 1.28 \\ \mathrm{Bhs} & 18-30 & 59.2 & 4.6 & 17.7 & 11.1 & 19.9 & 15.4 & 2.00 \\ \mathrm{Bt} & 30-46 & 42.2 & 4.1 & 10.2 & 11.5 & 18.2 & 16.0 & 1.66 \\ \mathrm{2E} & 46-53 & 18.5 & 0.7 & 1.7 & 9.0 & 0.8 & 10.2 & 0.98 \\ \text { 2Bw } & 53-66 & 56.5 & 5.3 & 12.7 & 13.3 & 15.4 & 18.7 & 1.97\end{array}$

Pedon 903 (Ultic Haplorthods)

\begin{tabular}{lrrrrrrrr} 
Oe & $10-0$ & - & - & - & - & - & - & - \\
A & $0-4$ & 18.8 & 0.9 & 3.0 & 8.3 & 2.2 & 10.3 & 0.98 \\
E & $4-13$ & 18.4 & 0.4 & 1.1 & 8.0 & 0.4 & 10.0 & 0.86 \\
EB & $13-30$ & 33.3 & 0.9 & 3.0 & 8.7 & 3.9 & 10.7 & 1.02 \\
Bhs/Bt & $30-44$ & 61.2 & 12.9 & 18.7 & 13.7 & 25.3 & 19.3 & 2.30 \\
BC & $44-70$ & 72.5 & 7.2 & 17.3 & 14.8 & 20.1 & 20.4 & 2.34 \\
\hline
\end{tabular}

${ }^{1}$ Subscripted $\mathrm{d}$, o and $\mathrm{p}$ are citrate-dithionite, oxalate and pyrophosphate extractable, respectively -: Not determined

also associated with an extremely low degree of base saturation $(\leqslant 10 \%)$ (Table 1$)$. The depths of maximum extractable $\mathrm{Fe}$ and $\mathrm{Al}$ are normally found in the B horizons of the three pedons. The order of $\mathrm{Fe}$ in this study is $\mathrm{Fe}_{\mathrm{d}}>\mathrm{Fe}_{\mathrm{p}}>\mathrm{Fe}_{\mathrm{o}}$, but there is no significant variation in $\mathrm{Al}$ content in the three extractions (Table 2). Based on the morphological characteristics and chemical analyses, Chen et al. (2002) demonstrated that Fe and Al were chelated by organic matter in the surface portion of the pedon to form the organo-metallic complexes under

Table 3. Clay mineral composition of the three soil pedons.

\begin{tabular}{|c|c|c|c|c|c|c|c|}
\hline Horizon & $\mathrm{V}^{1}$ & V-I & $\mathrm{I}$ & HIV & K & Q & G \\
\hline \multicolumn{8}{|c|}{ Pedon 901: Ultic Haplorthods } \\
\hline $\mathrm{O} / \mathrm{A}$ & +++ & + & + & + & + & ++ & - \\
\hline $\mathrm{E}$ & ++ & ++ & ++ & - & + & ++ & + \\
\hline Bhs & ++++ & ++ & + & + & + & + & + \\
\hline Bt1 & ++++ & + & + & ++ & + & + & + \\
\hline $\mathrm{C}$ & ++ & + & ++ & - & + & + & + \\
\hline \multicolumn{8}{|c|}{ Pedon 902: Ultic Haplorthods } \\
\hline $\mathrm{Oe} / \mathrm{A}$ & +++ & ++ & + & + & + & + & + \\
\hline $\mathrm{E}$ & ++ & ++ & + & - & + & + & + \\
\hline Bhs & ++ & ++ & + & + & + & ++ & + \\
\hline $\mathrm{Bt}$ & +++ & ++ & + & + & + & + & + \\
\hline $2 \mathrm{Bw}$ & +++ & + & + & + & + & + & + \\
\hline \multicolumn{8}{|c|}{ Pedon 903: Ultic Haplorthods } \\
\hline $\mathrm{E}$ & ++ & ++ & + & - & + & ++ & + \\
\hline EB & +++ & ++ & + & ++ & + & + & + \\
\hline $\mathrm{Bhs} / \mathrm{Bt}$ & +++ & + & + & + & + & + & + \\
\hline $\mathrm{BC}$ & ++ & + & ++ & - & - & + & + \\
\hline
\end{tabular}

${ }^{1} \mathrm{~V}=$ vermiculite; V-I = interstratified vermiculite-illite minerals; I = illite; HIV = hydroxy interlayered vermiculite; $\mathrm{K}=$ kaolinite; $\mathrm{Q}=$ quartz; $\mathrm{G}=$ gibbsite

$-:=$ not detectable; $+=\langle 10 \% ;++=10-25 \% ;+++=25-50 \% ;++++=>50 \%$ 
a flat microrelief. Most clays in suspension were leached progressively to a greater depth to form the argillic horizon (Bt) and some of the clay was also mixed sequentially with organo-metallic complexes and translocated into the upper portion of the spodic horizon (Bhs) within $50 \mathrm{~cm}$ of the soil surface. This pedogenic process was shown by micromorphology techniques (Chen et al., 2002)

\section{The distribution of clay minerals in the soils}

Vermiculite, interstratified vermiculite-illite minerals, illite, HIV, kaolinite, quartz and gibbsite with variable quantities are present in the three soils of this study (Table 3). The XRD patterns of clay fractions in the E horizons of pedon 901 are given in Figure 2 to explain the clay mineralogy of the surface soils.
Vermiculite was characterized by a $1.4 \mathrm{~nm}$ peak at $25^{\circ} \mathrm{C}$, collapsing to $1.0 \mathrm{~nm}$ when the $\mathrm{K}$-saturated clays were heated at $110^{\circ} \mathrm{C}$. Vermiculite-illite interstratified minerals were characterized by the basal XRD peak intermediate between 1.0 and $1.4 \mathrm{~nm}$ for $\mathrm{Mg}$-saturated clays (Sawhney, 1989). Glycerol treatment does not alter the spacings, but when the material was $\mathrm{K}$ saturated and heated to $100^{\circ} \mathrm{C}$, the layers of the vermiculite component collapsed to illite, resulting in a $1.0 \mathrm{~nm}$ peak and a series of higher orders. The broad peaks in this range indicated interstratified vermiculite-illite minerals in the O/A horizons. The XRD patterns of $\mathrm{Mg}$-saturated clay at $25^{\circ} \mathrm{C}$ indicated that illite $(1.0 \mathrm{~nm}$ and $0.334 \mathrm{~nm}$ peaks $)$, kaolinite $(0.72 \mathrm{~nm}$ peak), and quartz (0.426 and $0.334 \mathrm{~nm}$ peaks) were present. Gibbsite was reconfirmed by the peak $(0.485 \mathrm{~nm})$ which disappeared when the

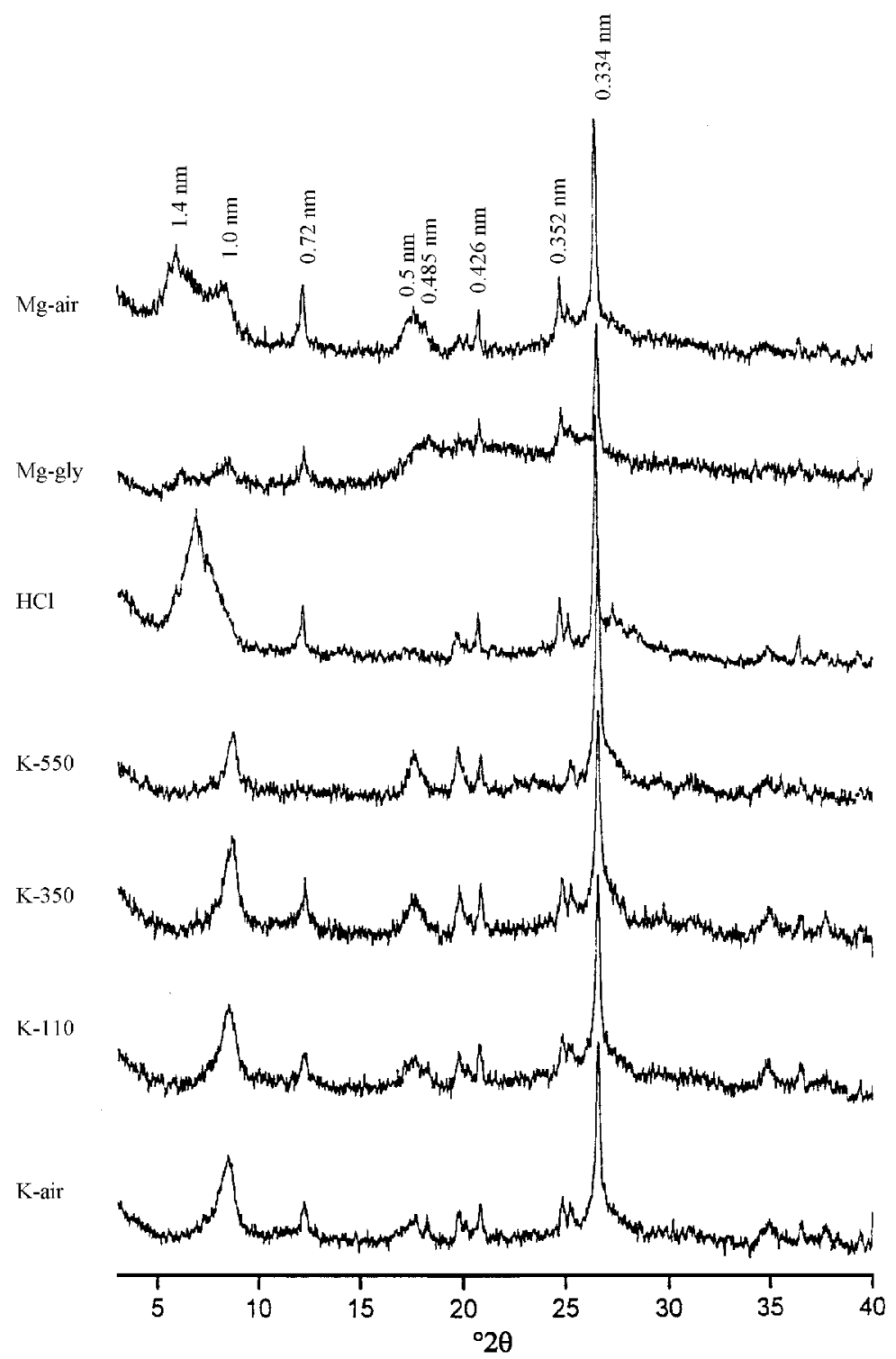

Figure 2. XRD patterns of the clay fraction in the E horizon of the pedon 901. 


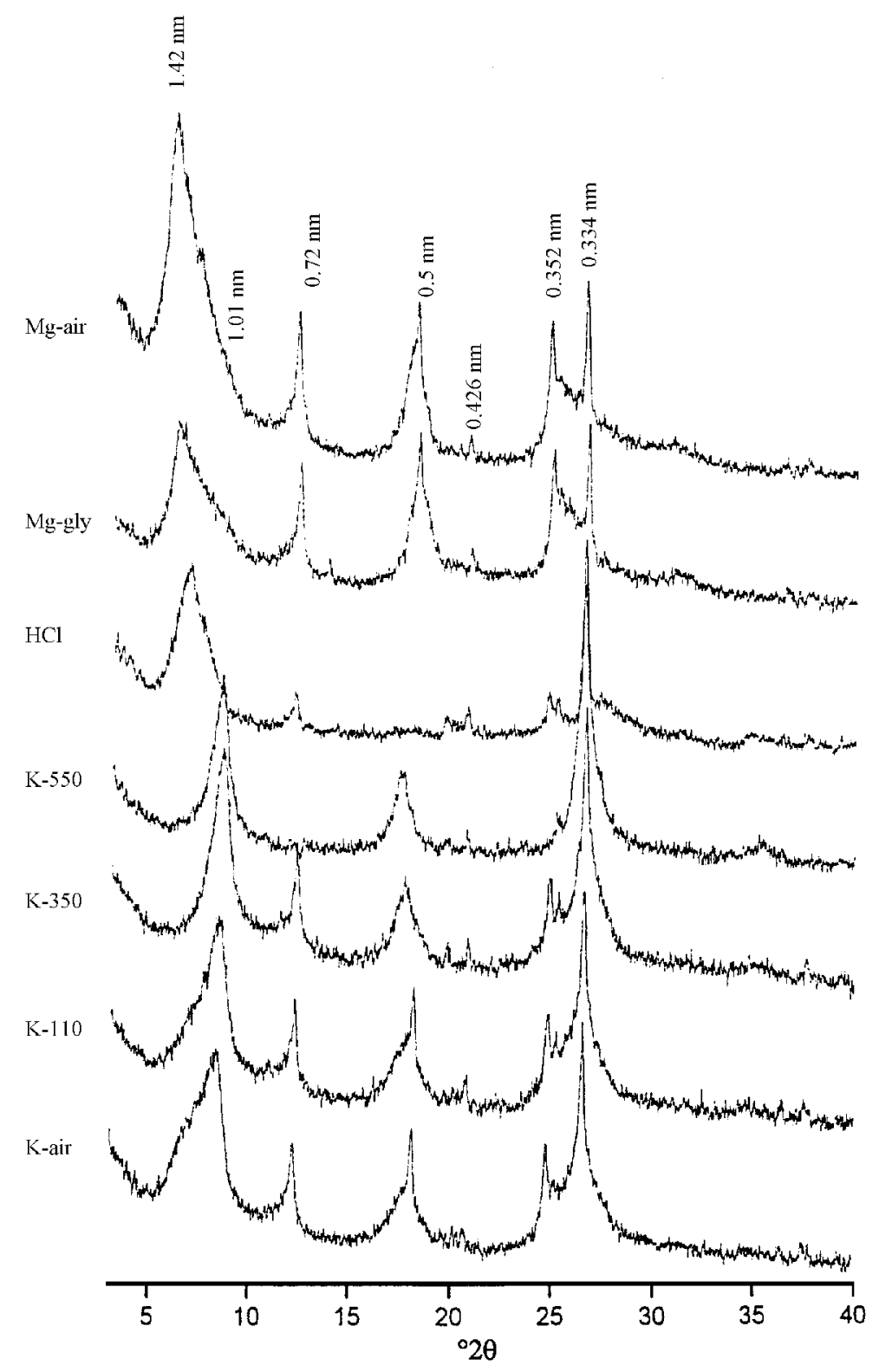

Figure 3. XRD patterns of the clay fraction in the Bhs horizon of the pedon 901.

K-saturated clays from the $\mathrm{E}, \mathrm{Bhs}$ and $\mathrm{Bt}$ horizons of pedon 901 were heated to $350^{\circ} \mathrm{C}$ (Figure 3). The $\mathrm{HCl}$ treatment without cationic saturation in this study was used to destroy the chlorite structure and to differentiate chlorite and kaolinite which have very different structures and pedogenic occurrences. Difficulties arise when they are present in mixtures. Weak reflections at $25^{\circ} \mathrm{C}$ in all figures are present at 12.5 and $25^{\circ} 2 \theta$, and they could be due to chlorite only, kaolinite only, or a mixture of the two. However, the residual peaks at 12.5 and $25^{\circ} 2 \theta$ indicated only the presence of kaolinite, not chlorite.

Identification of HIV was based on its failure to expand beyond $1.4 \mathrm{~nm}$ after $\mathrm{Mg}$ saturation and glycerol solvation and its incomplete collapse to $1.0 \mathrm{~nm}$ after $\mathrm{K}$ saturation and heat treatment (Chiang et al., 1999; Harris et al., 1987a; Rich, 1968). As a result, HIV was characterized by the collapse of the $1.4 \mathrm{~nm}$ peak toward $1.0 \mathrm{~nm}$ when the $\mathrm{K}$-saturated clay samples were heated to $350^{\circ} \mathrm{C}$ for the soil of the $\mathrm{O} / \mathrm{A}$ horizon of the pedon 901 (data not shown). The XRD patterns of the clay fraction from the O/A horizons of the other two pedons are also similar to pedon 901. Both vermiculite and HIV showed the $1.4 \mathrm{~nm}$ peak in the XRD patterns, but the greatest difference is the complete collapse toward $1.0 \mathrm{~nm}$ by the $\mathrm{K}$-saturated treatment at room temperature for highercharged vermiculite (Barnhisel and Bertsch, 1989). Therefore, the amount of vermiculite is greater than that of HIV associated with the collapse of $1.0 \mathrm{~nm}$ by the 
K-saturated clay of the surface soil of pedon 901 treated at different temperatures (Figure 2).

Except for HIV, the XRD patterns of the clay fraction in the $\mathrm{E}$ horizons were similar to those of the O/A horizons of the three pedons (Table 3). There is no HIV detectable in any of the $\mathrm{E}$ horizons of the three pedons (Figure 2, only pedon 901). The broad peaks between 1.0 and $1.4 \mathrm{~nm}$ on the XRD patterns of Mg-saturated clays indicated that appreciable amounts of interstratified vermiculite-illite minerals were present in all $\mathrm{E}$ horizons, and vermiculite was therefore identified by the $1.0 \mathrm{~nm}$ peak of K-saturated clays. Li et al. (1998b) indicated dominant amounts of illite and smectite, but no HIV in the E horizon of the loamy Spodosols in central Taiwan.

Significantly broad XRD peaks between 1.0 and $1.4 \mathrm{~nm}$ for the $\mathrm{Mg}$-saturated clays indicated that inter- stratified vermiculite-illite minerals were present in the Bhs horizon of three pedons (Figure 3, pedon 901 only). These broad peaks between 1.0 and $1.4 \mathrm{~nm}$ after $\mathrm{K}$ saturation was biased to $1.4 \mathrm{~nm}$ at room temperature, and completely collapsed to $1.0 \mathrm{~nm}$ at $350^{\circ} \mathrm{C}$. Hence, more vermiculite was identified than HIV in three pedons (Table 3). The XRD patterns of all Bt horizons of three pedons were similar to the Bhs horizons. This XRD pattern of the Bt 1 horizon of pedon 901 indicates that more HIV was identified than vermiculite-illite (Figure 4). The strong $1.4 \mathrm{~nm}$ peak of the Mg-saturated samples indicated the dominance of vermiculite, but small amounts of interstratified vermiculite-illite mineral were indicated by the weak, broad peaks between 1.0 and $1.4 \mathrm{~nm}$ in the Bt horizons. Illite and vermiculite were the dominant clay minerals in the $\mathrm{C}$

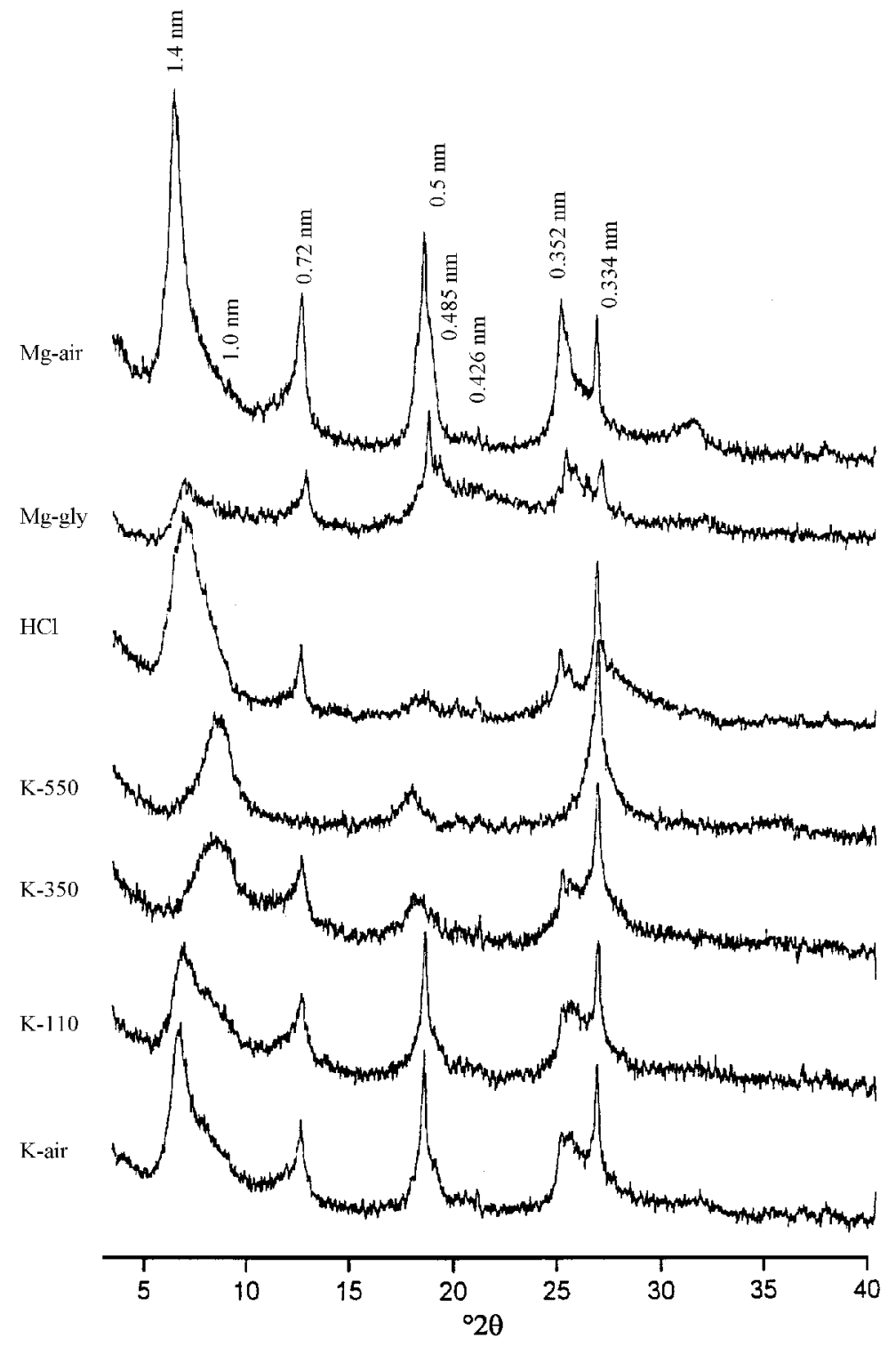

Figure 4. XRD patterns of the clay fraction in the Bt1 horizon of the pedon 901 . 
horizon of pedon 901 (Figure 5), but the other clay minerals in the three pedons studied appeared to be associated with different pedogenic processes (Table 3 ). It is noted that no smectite was identified because the $1.4 \mathrm{~nm}$ peak of the $\mathrm{Mg}$-saturated sample did not expand to $1.7 \mathrm{~nm}$ when treated with glycerol (Figures 2-5). Minor amounts of kaolinite and gibbsite are present throughout the soil profiles.

\section{Transformation of clay minerals}

Vermiculite and interstratified vermiculite-illite minerals are the dominant clay minerals, and the appreciable amounts of kaolinite and gibbsite showed consistent trends through the soil profiles in the study area. No HIV mineral was found in the E horizons, although variable amounts of HIV were found in other horizons, such as $\mathrm{O} / \mathrm{A}, \mathrm{Bhs}$ and $\mathrm{Bt}$ (Table 3). The maximum amount of HIV was found in the B horizon.
Barnhisel and Bertsch (1989) indicated that HIV is frequently distributed in the surface horizon and decreased with depth in Inceptisols, and Chiang et al. (1999) also reported that HIV has accumulated to a significant extent in the B horizons of Spodosol-like soils (Dystrochrepts) in the alpine forest soils of Taiwan. The maximum amounts of illite were formed in the $\mathrm{C}$ horizon, and the amounts of vermiculite increased with decreasing soil depth. The reverse trend occurred between illite and vermiculite through soil profiles. This indicated that illite was transformed to vermiculite in this strong weathering environment. Fanning et al. (1989) indicated that illite was easily transformed to expansible 2:1 minerals including vermiculite and smectite associated with loss of $\mathrm{K}$ and gain of hydrated exchangeable cations. The Al concentration is also crucial in the transformation to smectite. Ismail (1970) reported that the soils with low $\mathrm{Al}$ concentration and $\mathrm{pH}$

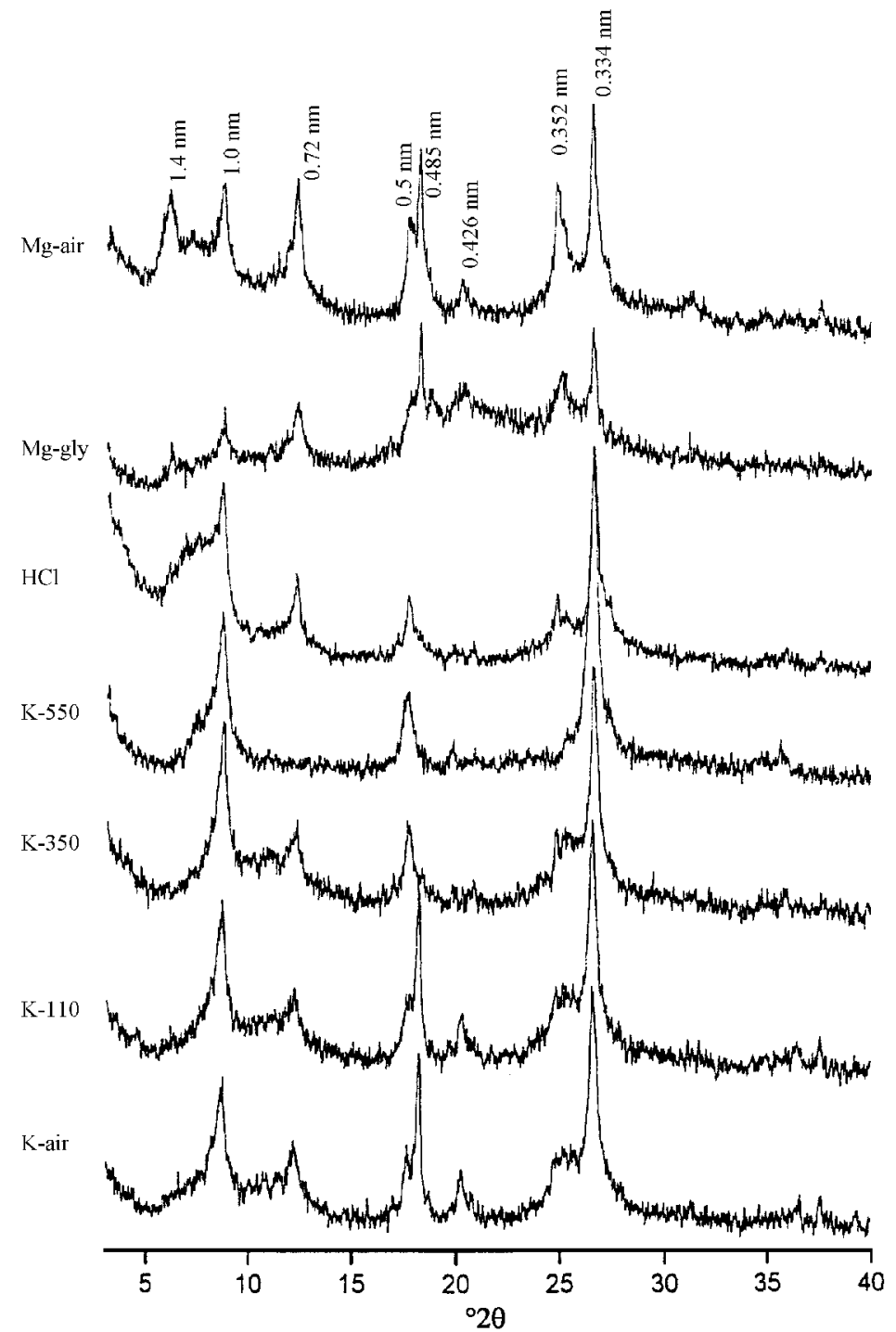

Figure 5. XRD patterns the of clay fraction in the C horizon of the pedon 901 . 
values above 6 or 7 favored the transformation of mica material to smectite, but at a soil $\mathrm{pH}<6$, mica weathers to vermiculite. Therefore, based on a soil $\mathrm{pH}$ of $<5.0$, with small amounts of exchangeable $\mathrm{K}$ and relatively large amounts of extractable $\mathrm{Al}$ in these conditions (Tables 1 and 2), the illite is gradually weathered to vermiculite, and not transformed to smectite under the good drainage and humid climate conditions in this study. The major phase of illite is dioctahedral, is a source of $\mathrm{Al}$ and acts as a precursor of HIV, kaolinite and gibbsite. Hsu (1989) indicated that basic rocks weathered directly to gibbsite, but siliceous acidic rocks, like sandstone and shale in this study, weathered through kaolinite to gibbsite. Jolicoeur et al. (2000) also indicated the presence of illitic mica and its weathering to vermiculite would provide preferential interlayer absorption sites for Al released from mineral weathering, thereby keeping the $\mathrm{Al}$ activity at low levels in the soil solution and inhibiting the formation of gibbsite. Therefore, the anti-gibbsite effect (Jackson, 1963) results in smaller amounts of kaolinite and gibbsite in this study.

In all Bhs and Bt horizons, the major clay minerals are vermiculite, interstratified vermiculite-illite minerals, and HIV. Chen et al. (2002) indicated that the special pedogenic processes of clay illuviation and podzolization occurred sequentially in the Alishan area, so that the clay coatings and organo-metallic complexes were found sequentially in the $\mathrm{Bhs}$ and $\mathrm{Bt}$ horizons of the soils (Tables 1 and 2). We expect that the first pedogenic process in the Bt horizon is the clay illuviation based on the fact that Bhs horizon normally occurred above the $\mathrm{Bt}$ horizon of the pedons. We propose that illite in the $\mathrm{C}$ horizon is the precursor for the formation of vermiculite and the HIV mineral in the udic soil moisture regime is associated with leaching caused by heavy rainfall. This may have interfered with the clay illuviation and later acidification, and leaching of bases occurred to an extent that HIV could be formed. Finally, podzolization took place including loss of $\mathrm{Al}$ from the interlayers in the top soil and deposition of $\mathrm{Fe}$ and $\mathrm{Al}$ ions in combination with organic acid in the Bhs horizon. This would stabilize the existing HIV minerals. Our suggestion is supported by the following evidence: (1) there are no other detectable 2:1 minerals in the three pedons, except vermiculite; (2) illuviation of spodic materials and clay enrich the Al content to promote the formation of hydroxy-interlayer minerals in the B horizons; and (3) when HIV was formed in the Bhs horizon, the metastable interlayered precipitates were presumably coated by the organo-metallic complexes and thus prevented from further weathering. Two hypotheses for the formation of HIV were proposed by Barnhisel and Bertsch (1989): it might be a weathering product of chlorite, or, perhaps more likely, it might arise from the formation of hydroxy-Al polymeric compounds within the interlayer spaces of vermiculite. We suggest the latter for the formation of HIV in this study.
The presence of HIV in the Bhs and Bt horizons of the three pedons correlated well with the greater $\mathrm{Fe}_{\mathrm{d}}$ and $\mathrm{Al}_{\mathrm{d}}$ contents (Table 2). Rich (1968) indicated that the most favorable soil conditions for HIV formation appear to be moderate acid soil $\mathrm{pH}(4.6-5.8)$, frequent wetting and drying cycles, and low organic matter content. The Al species would be largely in the form of $\mathrm{Al}^{3+}$ to allow insertion into the interlayer. Consequently, very acidic conditions in the $\mathrm{E}$ horizons (very low soil $\mathrm{pH}$ value ranging 3.7-4.4 in three pedons) (Table 1) is one possible reason that $\mathrm{HIV}$ is not detectable by XRD. On the other hand, the release and loss of $\mathrm{Al}$ from the $\mathrm{E}$ horizon (relatively lower $\mathrm{Al}_{\mathrm{d}}, \mathrm{Al}_{\mathrm{p}}$ and $\mathrm{Al}_{\mathrm{o}}$ contents) (Table 2) resulted in the reverse effect of HIV formation. The extremely low base saturation and good drainage conditions resulted in no smectite formation (Kittrick, 1971). As a consequence, we propose that the weathering sequence of clay minerals in these soils is: illite $\rightarrow$ vermiculite (or interstratified vermiculite-illite minerals) $\rightarrow$ HIV and vermiculite.

\section{CONCLUSIONS}

Significant clay accumulation in the Spodosols indicated that lessivage produced podzolization associated with very low soil $\mathrm{pH}$ values and base saturation. Vermiculite, interstratified vermiculite-illite minerals, illite, HIV, kaolinite, quartz and gibbsite with variable quantities were detected by XRD. Vermiculite and interstratified vermiculite-illite minerals are the dominant minerals. No HIV was present in the albic (E) horizons because the forest soils have very acid soil conditions and very low $\mathrm{Al}^{3+}$ content. The presence of HIV in the sequential formation of $\mathrm{Bt}$ and Bhs horizons of these Spodosols correlated well with relatively higher $\mathrm{Fe}_{\mathrm{d}}$ and $\mathrm{Al}_{\mathrm{d}}$ contents and more favorable $\mathrm{pH}$ ranges associated with the coatings of organo-metallic complexes which prevented further weathering. The weathering sequence of clay minerals in this study area is proposed as: illite $\rightarrow$ vermiculite (or interstratified vermiculite-illite minerals) $\rightarrow$ HIV and vermiculite.

\section{ACKNOWLEDGMENTS}

The authors thank the National Science Council of the Republic of China for providing partial financial support for this study (Grant No. NSC 89-2621-B-002-020). We also thank Dr M.K. Wang, Professor of the Department of Agricultural Chemistry, National Taiwan University, Taipei, Taiwan, for providing the X-ray diffractometer to determine the clay mineral compositions. Mr S.B. Wu and Miss C.C. Tsui and Miss C.C. Wu are acknowledged for their assistance with soil sampling. The Bureau of Forestry, Council of Agriculture, ROC, is also acknowledged for their help with soil sampling in the mountainous area.

\section{REFERENCES}

Andriesse, J.P. (1969) A study of the environment and characteristics of tropical podzols in Sarawak (East 
Malaysia). Geoderma, 3, 201-227.

Barnhisel, R.I. and Bertsch, P.M. (1989) Chlorite and hydroxyinterlayered vermiculite and smectite. Pp. 729-788 in: Minerals in Soil Environments (J.B. Dixon and S.B. Weed, editors). Soil Science Society of America, Madison, Wisconsin.

Brindley, G.W. (1980) Quantitative X-ray mineral analysis of clays. Pp. 411-438 in: Crystal Structures of Clay Minerals and their X-ray Identification (G.W. Brindley and G. Brown, editors). Monograph 5. Mineralogical Society, London.

Brown, G. and Brindley, G.W. (1980) X-ray diffraction procedures for clay mineral identification. Pp. 305-359 in: Crystal Structures of Clay Minerals and their X-ray Identification (G.W. Brindley and G. Brown, editors). Monograph 5. Mineralogical Society, London.

Chen, P.Y. (1977) Tables of key lines in X-ray powder diffraction patterns of minerals in clays and associated rocks. Printed by the authority of the State of Indiana, Bloomington, Indiana.

Chen, Z.S., Lin, K.C. and Chang, J.M. (1989) Soil characteristics, pedogenesis, and classification of Beichateinshan Podzolic soils, Taiwan. Journal of Chinese Agricultural Chemistry Society, 27, 145-155 (in Chinese, with English abstract, tables and figures).

Chen, Z.S., Liu, J.C. and Chiang, H.C. (1995) Soil properties, clay mineralogy, and genesis of some alpine forest soils in Ho-Huan Mountain area of Taiwan. Journal of Chinese Agricultural Chemistry Society, 33, 1-17.

Chen, Z.S., Hseu, Z.Y., Wu, S.P. and Tsai, C.C. (2002) Transition soils between Spodosols and Ultisols in subalpine forests of Taiwan. Pp. 137-145 in: Soil Classification 2001 (E. Micheli, F.O. Nachtergaele, R.J.A. Jones and L. Montanarella, editors). European Soil Bureau Research Department Report No. 7, EUR 20398 EN. Office for Official Publications of the European Communities, Luxembourg.

Chiang, H.C., Wang, M.K., Hong, K.H., White, N. and Dixon, J.B. (1999) Mineralogy of B horizons in alpine forest soils of Taiwan. Soil Science, 164, 111-122.

Fanning, D.S., Keramidas, V.Z. and El-Desoky, M.A. (1989) Micas. Pp 551-634 in: Minerals in Soil Environments (J.B. Dixon and S.B. Weed, editors). Soil Science Society of America, Madison, Wisconsin.

Gee, G.W. and Bauder, J.W. (1986) Particle-size analysis. Pp. 383-411 in: Methods of Soil Analysis, Part 1, 2nd edition (A. Klute et al., editors). Agronomy Monograph 9. Agronomy Society of America and the Soil Science Society of America, Madison, Wisconsin.

Harris, W.G. and Carlisle, V.W. (1987) Clay mineralogical relationships in Florida Haplaquods. Soil Science Society of America Journal, 51, 481 -484.

Harris, W.G. and Hollien, K.A. (1999) Changes in quantity and composition of crystalline clay across E-Bh boundaries of Alaquods. Soil Science, 164, 602-608.

Harris, W.G., Carlisle, V.W. and Van Rees, K.C.J. (1987a) Pedon zonation of hydroxy-interlayered minerals in Ultic Haplaquods. Soil Science Society of America Journal, 51, 1367-1372.

Harris, W.G., Carlisle, V.W. and Chesser, S.L. (1987b) Clay mineralogy as related to morphology of Florida soils with sandy epipedons. Soil Science Society of America Journal, 51, 1673-1677.

Hseu, Z.Y., Chen, Z.S. and Wu, Z.D. (1999) Characterization of placic horizons in two subalpine forest Inceptisols. Soil Science Society of America Journal, 63, 941-947.

Hsu, P.H. (1989) Aluminum hydroxides and oxyhydroxides. Pp. 331-378 in: Minerals in Soil Environments (J.B. Dixon and S.B. Weed, editors). Soil Science Society of America, Madison, Wisconsin.
Ismail, F.T. (1970) Biotite weathering and clay formation in arid and humid regions, California. Soil Science, 109, $257-261$.

Jackson, M.L. (1963) Aluminum bonding in soils: A unifying principle in soil science. Soil Science Society of America Proceedings, 27, 1-10.

Jolicoeur, S., Ildefonse, Ph. and Bouchard, M. (2000) Kaolinite and gibbsite weathering of biotite within saprolites and soils of central Virginia. Soil Science Society of America Journal, 64, $1118-1129$.

Kittrick, J.A. (1971) Montmorillonite equilibria and the weathering environment. Soil Science Society of America Proceedings, 35, 815-820.

Li, S.Y., Chen, Z.S. and Liu, J.C. (1998a) Subalpine loamy Spodosols in Taiwan: Characteristics, micromorphology, and genesis. Soil Science Society of America Journal, 62, $710-716$.

Li, S.Y., Chen, Z.S. and Liu, J.C. (1998b) Weathering sequence of clay minerals in loamy Spodosols of central Taiwan. Journal of the Agricultural Association of China, 183, $51-68$.

Loveland, P.J. and Digby, P. (1984) The extraction of Fe and Al by $0.1 \mathrm{M}$ pyrophosphate solutions: a comparison of some techniques. Journal of Soil Science, 35, 243-250.

Lundstrom, U.S., Van Breemen, N. and Bain, D.C. (2000) The podzolization processes: a review. Geoderma, 94, 91-108.

McKeague, J.A. and Day, J.H. (1966) Dithionite and oxalate extractable $\mathrm{Fe}$ and $\mathrm{Al}$ as aids in differentiating various classes of soils. Canadian Journal of Soil Science, 46, $13-22$.

McKeague, J.A., DeConinck, F. and Franzmeier, D.P. (1983) Spodosols. Pp. 217-252 in: Pedogenesis and Soil Taxonomy: Vol. II. The Soil Orders (L.P. Wilding, N.E. Smeck, and G.F. Hall, editors). Elsevier, New York.

McLean, E.O. (1982) Soil $\mathrm{pH}$ and lime requirement. Pp. 199-224 in: Methods of Soil Analysis, Part 2, 2nd edition (A. L. Page et al., editors). Agronomy Monograph 9. Agronomy Society of America and the Soil Science Society of America, Madison, Wisconsin.

Mehra, O.P. and Jackson, M.J. (1960) Iron oxides removed from soils and clays by a dithionite-citrate system buffered with sodium bicarbonate. Clays and Clay Minerals, 7, 317-327.

Nelson, D.W. and Sommers, L.E. (1982) Total carbon, organic carbon, and organic matter. Pp. 539-577 in: Methods of Soil Analysis, Part 2, 2nd edition (A. L. Page et al., editors). Agronomy Monograph 9. Agronomy Society of America and the Soil Science Society of America, Madison, Wisconsin.

Padley, E.A., Bartelli, L.J. and Trettin, C.C. (1985) Spodic horizon criteria applied to soils of northern Michigan. Soil Science Society of America Journal, 49, 401-405.

Rhoades, J.D. (1982) Cation exchange capacity. Pp. 149-157 in: Methods of Soil Analysis, Part 2, 2nd edition (A. L. Page et al., editors). Agronomy Monograph 9. Agronomy Society of America and the Soil Science Society of America, Madison, Wisconsin.

Rich, C.I. (1968) Hydroxy interlayers in expansible layer silicates. Clays and Clay Minerals, 16, 15-30.

Sawhney, B.L. (1989) Interstratification in layer silicates. Pp. 789-828 in: Minerals in Soil Environments (J.B. Dixon and S.B. Weed, editors). Soil Science Society of America, Madison, Wisconsin.

Soil Survey Staff (1999) Soil Taxonomy: A basic system of soil classification for making and interpreting soil surveys. USDA-NRCS, Agricultural Handbook No. 436, 2nd edition, US Government Printing Office, Washington, D.C.

(Received 6 August 2001; revised 7 May 2002; Ms. 569) 